\title{
Effect of protein supplementation on milk production and metabolism of dairy cows grazing tropical grass
}

\author{
M. A. C. Danes, ${ }^{*}$ L. J. Chagas, ${ }^{*}$ A. M. Pedroso, $\dagger$ and F. A. P. Santos ${ }^{* 1}$ \\ *Department of Animal Science, University of São Paulo, Piracicaba, São Paulo, 13418900, Brazil \\ †Empresa Brasileira de Pesquisa Agropecuária, Sao Carlos, São Paulo, 13560970, Brazil
}

\begin{abstract}
The objectives of this study were to determine if midlactation dairy cows (Bos taurus L.) grazing intensively managed elephantgrass would have their protein requirement met exclusively with the pasture and an energy concentrate, making the use of protein ingredients unnecessary, as well as to determine the dietary crude protein $(\mathrm{CP})$ content that would optimize the efficiency of $\mathrm{N}$ utilization (ENU). Thirty-three Holstein and crossbred (Holstein $\times$ Jersey) midlactation dairy cows, producing approximately $20 \mathrm{~kg} / \mathrm{d}$, were grouped within breed into 11 blocks according to milk yield and days in milk. Within blocks, cows were randomly assigned to 1 of 3 treatments and remained in the study for 11 wk. The control treatment contained only finely ground corn, minerals, and vitamins, and it was formulated to be $8.7 \%$ CP. Two higher levels of CP (formulated to be 13.4 and $18.1 \%$ ) were achieved by replacing corn with solvent-extracted soybean meal (SSBM). Pasture was fertilized with $50 \mathrm{~kg}$ of $\mathrm{N} /$ ha after each grazing cycle and averaged $18.5 \%$ CP (dry matter basis). No differences were observed in milk yield or milk fat, protein, and casein content or casein yield. In addition, pasture intake was not different among treatments. Milk urea $\mathrm{N}$ increased linearly as the concentrate $\mathrm{CP}$ content increased. Cows fed the $8.7 \% \mathrm{CP}$ concentrate had higher ENU. In another experiment, 4 ruminally cannulated Holstein dry cows were used in a metabolism trial designed in a $4 \times 4$ Latin square. Cows were fed the same treatments described as well as a fourth treatment with $13.4 \% \mathrm{CP}$ in the concentrate, in which urea replaced $\mathrm{SSBM}$ as the main $\mathrm{N}$ source. Ruminal volatile fatty acid concentration and microbial synthesis were not affected by levels or sources of $\mathrm{N}$ in the concentrate. Ruminal $\mathrm{NH}_{3} \mathrm{~N}$ content increased as the concentrate $\mathrm{CP}$ content increased. Inclusion of SSBM in the concentrate did not increase production and decreased the ENU of midlactation dairy cows grazing on tropical
\end{abstract}

Received April 9, 2012.

Accepted September 1, 2012.

${ }^{1}$ Corresponding author: fapsantos@usp.br forage. Supplementation of an $8.7 \% \mathrm{CP}$ concentrate, resulting in a diet with $\mathrm{CP}$ levels between 15.3 and $15.7 \%$ of dry matter, was sufficient to meet the protein requirements of such milk production, with the highest ENU (18.4\%).

Key words: tropical pasture, protein supplementation, nitrogen metabolism

\section{INTRODUCTION}

During the last $10 \mathrm{yr}$, grazing management techniques have been implemented to improve the nutritive value and intake of tropical forage consumed by grazing dairy cows in Brazil (Pedreira et al., 2005; Da Silva and Nascimento Junior, 2007; Voltolini et al., 2008). High doses of $\mathrm{N}$ fertilization, between 200 and $500 \mathrm{~kg} / \mathrm{ha}$, are required to allow stocking rates of 6 to 10 cows/ha during the 6- to 7-mo rainy season (Santos et al., 2005). As a result of $\mathrm{N}$ fertilization, not only does the pasture $\mathrm{CP}$ content increase, but this increase is also accompanied by a decrease in NDF content (Johnson et al., 2001). A recent study concluded at the University of Wisconsin evaluated the nutrient composition and fiber digestibility of intensively managed tropical grasses collected in Brazil (Lopes, 2011). The 106 samples (from 6 different species) came from areas fertilized with 200 to $400 \mathrm{~kg}$ of $\mathrm{N} /$ ha with fewer than $30 \mathrm{~d}$ of regrowth, and $\mathrm{CP}$ and NDF content ranged from 14 to $21 \%$ and 60 to $63 \%$, respectively. Those results showed that tropical grasses can present adequate nutritive value when well managed.

Additionally, $\mathrm{N}$ fertilizer accelerates plant growth; therefore, an adjustment in grazing management is necessary to avoid offering the animal old forage with a high fibrous content. The optimal physiological stage of utilization of grass pastures, from both the plant and animal standpoint, has been shown to be the point at which the canopy intercepts $95 \%$ of the incident light (Parsons et al., 1988; Carnevalli et al., 2006), and this stage seems to be well correlated with a specific canopy height for each grass species (Carnevalli et al., 2006; Giacomini et al., 2009; Voltolini et al., 2010). Those findings led to a new rotational grazing management 
approach, in which grazing intervals are variable and dependent on sward height, rather than the traditional method of a fixed number of days. In fertilized areas during the rainy season, the variable interval is usually shorter than the fixed number of days traditionally recommended, leading to a less mature plant being offered to the animal, with better nutritive value.

When the chemical composition of intensively managed tropical grasses (CP levels ranging from 15 to $21 \%$ DM) was used in the NRC (2001) and Cornell Net Carbohydrate and Protein System (CNCPS, version 6.1; Cornell University, Ithaca, NY) models, both suggested that only energy supplementation was needed to meet the nutritional requirements of grazing dairy cows producing $20 \mathrm{~kg} / \mathrm{d}$ of milk. According to the NRC (2001) model, more than $18 \% \mathrm{CP}$ in the forage already leads to an excess supply of MP, even for dairy cows supplemented with energy ingredients only in the concentrate.

However, regardless of the evidence provided by the models, resistance exists among the dairy farmers about reducing the $\mathrm{CP}$ of the diet. Concentrate mixtures sold commercially for grazing dairy cows in Brazil usually contain 17 to $25 \% \mathrm{CP}$, even when cows graze pasture that is intensively managed. Likewise, in Louisiana and Mississippi, a survey with 40 grazing dairy farms reported that $75 \%$ of the locations were overfeeding $\mathrm{CP}$, using concentrates with more than $18 \% \mathrm{CP}$ (McCormick et al., 2001). Overfeeding CP not only increases feed cost, but also increases the energy required to eliminate the excess N (NRC, 1989) and reduces the efficiency of $\mathrm{N}$ utilization (ENU). Moreover, $\mathrm{N}$ excretion may potentially result in environmental problems, such as $\mathrm{N}$ volatilization or leaching into the groundwater (Tamminga, 1992).

The resistance in reducing dietary $\mathrm{CP}$ for grazing cows fed tropical grasses might be related to concerns about the accuracy of model predictions of pasture DMI and the maintenance requirements of grazing cows because the equations were developed mainly for confinement animals and are associated with the limited availability of studies on the optimal protein level in diets for dairy cows grazing intensively managed tropical grasses. Voltolini et al. (2008) evaluated 3 levels of CP $(17.3,21.2$, and $25 \%$ of $\mathrm{DM})$ in the concentrate for cows grazing elephantgrass with $12 \% \mathrm{CP}$ and found no treatment effect on milk or milk solids yield. In another study, Pereira et al. (2009) tested 3 levels of CP (15.2, 18.2 , and $21.1 \%$ of $\mathrm{DM}$ ) in the concentrate for cows grazing elephantgrass with $13.9 \% \mathrm{CP}$ and did not find any advantage in DMI or milk yield of increased levels of $\mathrm{CP}$ in the diet. However, both studies still used protein ingredients in the concentrates, leading to higher levels of $\mathrm{CP}$ than an exclusively energy concentrate, which was suggested to be sufficient by the model simulation. Additionally, the forage CP observed in both studies was lower than was achievable with intensively managed rotational grazing.

Therefore, the objective of this study was to determine whether midlactation dairy cows grazing intensively managed tropical grasses (high $\mathrm{N}$ fertilizer doses and variable grazing intervals) would have their protein requirements met only by the forage plus a concentrate with energy ingredients, confirming what the model simulations have been showing as adequate and making the use of protein ingredients unnecessary in the concentrate of those cows. This study also aimed to estimate the optimal dietary CP to improve ENU in an intensively managed tropical grazing system.

\section{MATERIALS AND METHODS}

\section{Grazing Management and Pasture Measurements}

The 6.5 ha of pasture used in the study was composed of elephantgrass (Pennisetum purpureum), cv. Cameroon (70\% of the paddocks) and cv. Napier (30\% of the paddocks), and it was fertilized with $50 \mathrm{~kg}$ of N/ ha after each grazing cycle. All cows from the lactation and ruminal metabolism trials grazed together, and a new paddock $\left(2,000 \mathrm{~m}^{2}\right)$ was allotted for the animals every day, after the evening milking, with free access to natural shade and fresh water. The rotational grazing management was based on canopy height, with $103 \mathrm{~cm}$ as the entrance height for Cameroon and $90 \mathrm{~cm}$ for Napier, both previously determined as the point at which the canopy intercepted $95 \%$ of incident light (Voltolini et al., 2010; Da Silva, University of São Paulo, Piracicaba, São Paulo, Brazil, personal communication).

Experimental cows grazed the paddock as the first group, and they were kept in the paddock for $1 \mathrm{~d}$ only, grazing the canopy down to an average of $64.2 \mathrm{~cm}$ (Table 1) throughout the trial. A group of animals with a lower requirement (dry cows and pregnant heifers) was used to graze the pasture down to its residual postgrazing sward height $[52 \pm 5 \mathrm{~cm}$ (mean $\pm \mathrm{SD}$ )]. The average interval between grazing cycles was $28 \mathrm{~d}$, and the average stocking rate, considering only the experimental animals (i.e., not including the second group that grazed down the paddocks to the final residual height), was 5 cows/ha.

Sward height measurements were taken every day before the experimental animals entered the paddock, after they left, and also after the second group of animals was removed, for an average of 20 randomized points in each measurement. Forage mass and morphological composition were determined weekly on 3 consecutive 
Table 1. Pasture characteristics at pre- and postgrazing

\begin{tabular}{lcc}
\hline Characteristic & Pregrazing & Postgrazing $^{1}$ \\
\hline Sward height, cm & 102.2 & 62.4 \\
Pasture cover, $\mathrm{kg}$ of DM/ha & 9,600 & 6,250 \\
Leaves, \% of pasture DM & 42.6 & 25.5 \\
Stem, \% of pasture DM & 38.0 & 47.6 \\
Dead material, \% of pasture DM & 19.4 & 26.9 \\
Leaf:stem ratio & 1.12 & 0.53 \\
\hline
\end{tabular}

${ }^{1}$ After the experimental animals left the paddock, before the entrance of the second group of animals.

days, before the experimental cows entered the paddock and after they left. In each evaluation, 4 randomized points were selected in the paddock, and in each point, the material within a square frame $\left(1 \mathrm{~m}^{2}\right)$ was cut to ground level. Total forage mass was weighed, and a representative subsample of $0.5 \mathrm{~kg}$ was taken and separated into leaf blades, stems (including leaves sheaths), and dead material (as indicated by more than $50 \%$ of the tissue area being senescent) to determine the sward morphological composition.

Pre- and postgrazing sward height, forage mass, and morphological composition are presented in Table 1 . Postgrazing refers to the moment that the experimental animals were removed from the paddock, before the second group had access to it. Those characteristics, particularly the leaf:stem ratio in the pregrazing canopy and leaf content in the postgrazing canopy, suggested an adequate sward structure that facilitated pasture intake (Stobbs, 1973; Palhano et al., 2007). In tropical grasses, harvest limitations resulting from sward structure have been pointed out as the main constraint for pasture intake (Palhano et al., 2007). According to Fonseca et al. (2012), to optimize forage DMI, cattle should graze up to $40 \%$ of the canopy height. In the present study, experimental cows grazed the pasture down from 90 to $103 \mathrm{~cm}$ to $62.4 \mathrm{~cm}$. Daily forage mass disappearance averaged $18.6 \mathrm{~kg}$ of $\mathrm{DM} /$ cow, which is twice the NRC (2001) forage intake prediction for those cows and most likely did not impose any limitation on forage intake and cow responses to protein treatments.

Hand-plucked forage was sampled weekly on 3 consecutive days, twice daily, at the beginning of grazing periods after each milking. The samples were plucked between the thumb and a backward-bent forefinger, simulating the cows' grazing as closely as possible, by the same person over the entire experiment (De Vries, 1995). Pasture samples were dried in a forced-air oven at $55^{\circ} \mathrm{C}$ for $72 \mathrm{~h}$, ground through a 1-mm screen (Wiley mill; Arthur H. Thomas, Philadelphia, PA). A single composite was prepared by mixing equal amounts of DM from individual samples and was stored at room temperature until the analysis.

\section{Lactation Trial}

The study was conducted in Piracicaba, São Paulo, Brazil $\left(22.7^{\circ} \mathrm{S}, 47.6^{\circ} \mathrm{E}\right.$ and $546 \mathrm{~m}$ altitude), from December 2008 to February 2009. Thirty-three Holstein and crossbred (Holstein $\times$ Jersey) cows were used, 27 multiparous and 6 primiparous, averaging (mean \pm SD) $129 \pm 86$ DIM, $21.5 \pm 4.1 \mathrm{~kg}$ of milk/d, and 451 $\pm 71 \mathrm{~kg}$ of $\mathrm{BW}$ at the beginning of the trial. Within breed (Holstein or crossbred), cows were grouped for similar milk yield and DIM, with milk yield being the higher order criterion, into 11 blocks. All cows received the same diet for a standardization period of $30 \mathrm{~d}$, after which they were randomly assigned within blocks to concentrate mixtures with 3 levels of $\mathrm{CP}$ and fed these treatments for $11 \mathrm{wk}$. The control treatment contained only finely ground corn, minerals, and vitamins, and it was formulated to be $8.7 \% \mathrm{CP}$ (Table 2). The 2 higher levels of CP (formulated to be 13.4 and 18.1\%) were achieved by replacing corn with solvent-extracted soybean meal (SSBM). One cow was removed in the third week of the trial because of health issues unrelated to the treatment. All procedures involving the animals were approved by the Ethical Committee for Animal Research of the University of São Paulo, Piracicaba.

Concentrates were fed individually twice a day at 0500 and $1600 \mathrm{~h}$, before each milking, at a rate of $1 \mathrm{~kg}$ of concentrate $/ 3 \mathrm{~kg}$ of milk, established based on the milk yield at the end of the standardization period and maintained during the experimental period.

Samples of concentrate were collected weekly, stored at room temperature, and pooled on a treatment basis for analysis. Cows were milked twice daily at 0600 and $1700 \mathrm{~h}$, and the milk yield of each milking was recorded weekly on 3 consecutive days. Milk samples from both milkings were collected once a week, on the second day of milk yield recording, and pooled on a cow per week basis. The samples were collected in vials with a bronopol preservative pill, stored in a refrigerator, and analyzed within $48 \mathrm{~h}$ of sampling. Yields of fat, CP, and $\mathrm{CN}$ were computed weekly using the mean of the 3-d milk yield.

Cows were weighed in the beginning and at the end of the trial on 2 consecutive days after the morning milking. Blood samples were taken from the coccygeal vessels of the cows $4 \mathrm{~h}$ after the morning concentrate feeding, in the beginning, middle, and end of the experimental period. Samples were centrifuged $(3,000 \times$ $g, 4^{\circ} \mathrm{C}, 20 \mathrm{~min}$ ), and plasma was stored at $-20^{\circ} \mathrm{C}$.

Pasture intake was calculated from total fecal excretion and feed digestibility at 1 time during wk 10 of the trial. To estimate total fecal excretion, cows were orally dosed with 2 paper capsules containing $10 \mathrm{~g}$ each 
Table 2. Composition of the forage and experimental concentrates

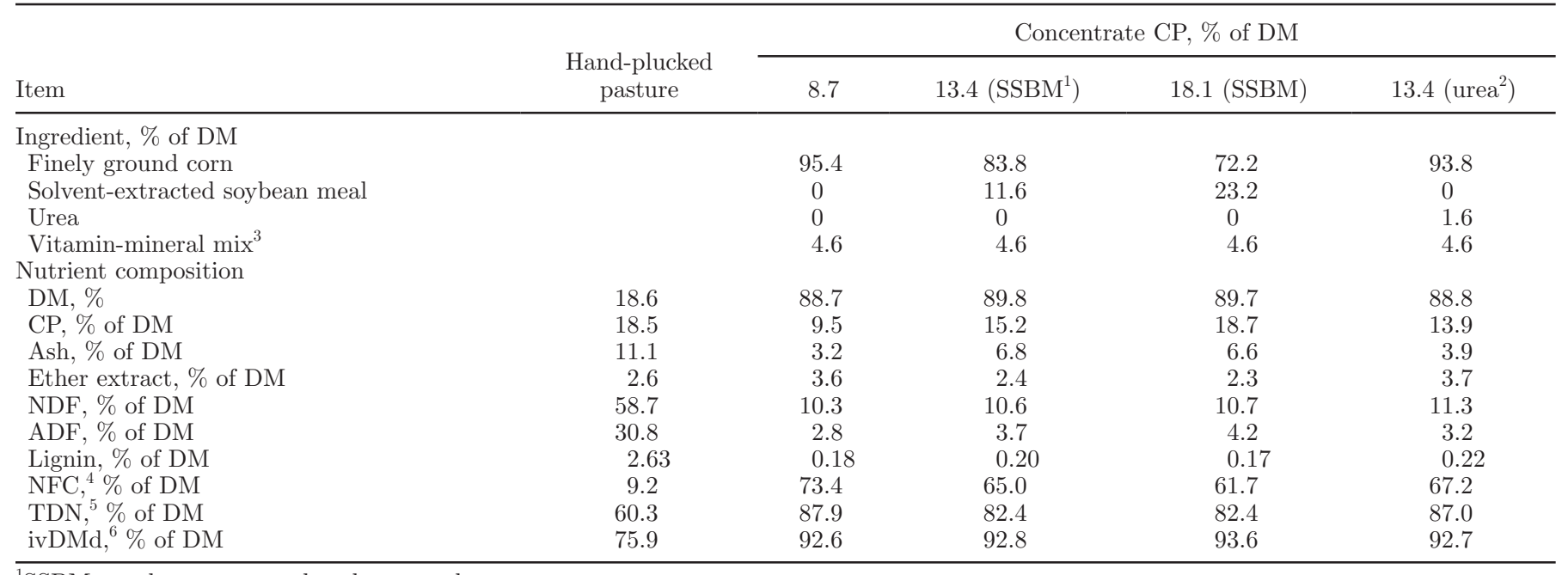

${ }^{1} \mathrm{SSBM}=$ solvent-extracted soybean meal.

${ }^{2}$ Treatment with urea as the $\mathrm{N}$ source was present only in the ruminal metabolism trial.

${ }^{3}$ Provided the following per kilogram of product DM: $55 \mathrm{~g}$ of P, $220 \mathrm{~g}$ of Ca, $105.5 \mathrm{~g}$ of Cl, $70 \mathrm{~g}$ of Na, $35 \mathrm{~g} \mathrm{of} \mathrm{Mg,} 22 \mathrm{~g}$ of S, $1,500 \mathrm{mg}$ of Mn, $500 \mathrm{mg}$ of $\mathrm{Fe}, 1,550 \mathrm{mg}$ of $\mathrm{Zn}, 450 \mathrm{mg}$ of $\mathrm{Cu}, 50 \mathrm{mg}$ of Co, $40 \mathrm{mg}$ of I, $20 \mathrm{mg}$ of Se, 90,000 IU of vitamin A, 75,000 IU of vitamin $\mathrm{D}_{3}, 1,000$ of vitamin E.

${ }^{4}$ Nonfiber carbohydrates $=100-(\mathrm{NDF}+$ ash $+\mathrm{CP}+$ ether extract $)$.

${ }^{5}$ Total digestible nutrients calculated from the formula of Weiss et al. (1992).

${ }^{6}$ In vitro DM digestibility (Tilley and Terry, 1963).

of powdered chromium oxide $\left(\mathrm{Cr}_{2} \mathrm{O}_{3}\right)$ per day, 1 before each milking, for 12 d. Feces were collected twice a day, before each milking, during the last $5 \mathrm{~d}$ of $\mathrm{Cr}_{2} \mathrm{O}_{3}$ dosing, dried at $55^{\circ} \mathrm{C}$ for $72 \mathrm{~h}$, and ground through a 1-mm screen (Wiley mill; Arthur H. Thomas), and equal DM from each fecal subsample was mixed to obtain 1 composite sample for each cow. To calculate in vivo feed digestibility, the internal marker indigestible DM (iDM) was estimated using an in situ incubation for $240 \mathrm{~h}$ (Casali et al., 2008) of fecal samples from individual cows and feed composite samples (3 concentrate mixes and 1 hand-plucked pasture sample). The hand-plucked pasture sample used in this procedure was collected during the same week as $\mathrm{Cr}_{2} \mathrm{O}_{3}$ dosing, rather than the composite of the whole trial, to be better associated with the fecal samples. Briefly, the samples were ground through a 1-mm screen (Wiley mill; Arthur H. Thomas), placed in filter bags (F-57; Ankom Technology, Macedon, NY), and incubated in triplicate in the rumen of a cow fed a diet of 70:30 grass hay and protein concentrate supplement. After the incubation, the bags were washed and dried in a forced-air oven at $105^{\circ} \mathrm{C}$ for $12 \mathrm{~h}$ for determination of the iDM. The iDM contents of concentrate and pasture were divided by the iDM content of the feces of each cow to calculate the indigestibility of feeds in each animal (in vivo digestibility).

\section{Ruminal Metabolism Trial}

This trial was conducted simultaneously with the lactation trial to provide ruminal metabolic information that could help us understand the performance results of the lactation study. Care must be taken when using data generated from dry cows to explain results obtained with lactating cows because their BW, DMI, and metabolic requirements are different. Although Bargo et al. (2001) found no difference in ruminal metabolism between lactating and dry cows, they used animals with similar BW, which was not the case in the present study, in which cows in the lactation study averaged $451 \mathrm{~kg}$ and cows in the ruminal metabolism study averaged $660 \mathrm{~kg}$ at the beginning of the trials.

Four ruminally cannulated Holstein dry cows [660 \pm $110 \mathrm{~kg}$ of BW (mean $\pm \mathrm{SD})]$ were used in a $4 \times 4$ Latin square design and assigned to the same 3 treatments fed in the lactation study plus a fourth treatment containing $13.4 \% \mathrm{CP}$, with urea rather than SSBM as the N source (Table 1). The SSBM was replaced with urea to evaluate the response of the cows to a $\mathrm{N}$ source with a rapid rate of ruminal degradation. Grazing management and concentrate feeding were the same as described for the lactation experiment, except that each cow received $5.0 \mathrm{~kg}$ of DM of concentrate per day. That level was established to simulate the forage:concentrate ratio of the 
lactating cow diet, based on the forage intake predicted by the NRC (2001) for both groups of cows.

Each experimental period lasted $15 \mathrm{~d}$ and consisted of $10 \mathrm{~d}$ for adaptation and $5 \mathrm{~d}$ for data collection. Ruminal fluid was collected from 3 locations in the ventral rumen on d 11 of each period by using a probe made with a polyvinyl chloride pipe with small holes in an end to avoid ruminal content being collected and a hose inside the pipe that was connected to a syringe in the other end. Samples were taken at 0500 (just before the morning concentrate feeding), 0700, 1000, 1300, 1600 (just before the evening concentrate feeding), 1800, 2100,0000 , and $0300 \mathrm{~h}$. The $\mathrm{pH}$ was measured immediately after collection, and a $60-\mathrm{mL}$ aliquot of each sample was stored at $-20^{\circ} \mathrm{C}$.

Blood samples were taken from the coccygeal vessels of each cow on the last day of each period, $4 \mathrm{~h}$ after the morning concentrate feeding. Samples were centrifuged $\left(3,000 \times g, 4^{\circ} \mathrm{C}, 20 \mathrm{~min}\right)$ and plasma was stored at $-20^{\circ} \mathrm{C}$.

Fecal samples were collected in the last $5 \mathrm{~d}$ of each period, twice daily, during feeding time. Samples were dried at $55^{\circ} \mathrm{C}$ for $72 \mathrm{~h}$ and ground through a 1-mm screen (Wiley mill; Arthur H. Thomas), and equal DM from each fecal subsample was mixed to obtain $1 \mathrm{com}-$ posite sample for each cow per period.

Microbial synthesis was estimated by the purine derivative excretion method (Stangassinger et al., 1995). Spot urine samples (Valadares et al., 1999) were collected twice daily on the last $3 \mathrm{~d}$ of each period during each feeding time. Samples $(60 \mathrm{~mL})$ were acidified with $2 \mathrm{~mL}$ of $6 \mathrm{~N} \mathrm{HCl}$ and immediately stored at $-20^{\circ} \mathrm{C}$. Total urine production was estimated by creatinine content of each sample, assuming that excretion of creatinine was constant at $0.213 \mathrm{mmol} / \mathrm{kg}$ of BW (Chizzotti et al., 2008).

\section{Chemical Analysis and Calculations}

Composite feed samples were analyzed for DM at $105^{\circ} \mathrm{C}$ and ash (AOAC, 1990), for total $\mathrm{N}$ using a combustion assay (Leco FP-2000 N Analyzer; Leco Instruments Inc., St. Joseph, MI), for NDF using $\mathrm{Na}_{2} \mathrm{SO}_{3}$ for all the samples and heat-stable $\alpha$-amylase for concentrate samples, for ADF (both NDF and ADF are expressed here on an ash-free basis), for NIDN and ADIN without $\mathrm{Na}_{2} \mathrm{SO}_{3}$ (Van Soest et al., 1991), and for in vitro DM digestibility (ivDMd; Tilley and Terry, 1963; modified by Goering and Van Soest, 1970). Handplucked pasture samples were also analyzed for soluble N (Krishnamoorthy et al., 1982) and NPN (Licitra et al., 1996) to quantify the CNCPS protein fractions (Sniffen et al., 1992). Feed and fecal samples were analyzed for indigestible DM (DM remaining after $240 \mathrm{~h}$ of in situ incubation; Casali et al., 2008).
Milk samples were analyzed for fat and CP by infrared analysis with a Bentley 2000 midinfrared instrument (Bentley Instruments, Chaska, MN), for MUN with a ChemSpec 150 system (Bentley Instruments), and for CN with a Foss 6000 FTIV instrument (Foss North America Inc., Eden Prairie, MN).

Plasma samples were thawed at room temperature, homogenized, and analyzed for plasma urea N (PUN) by a phenol-hypochlorite procedure (Chaney and Marbach, 1962). Fecal samples from the lactation trial were analyzed for $\mathrm{Cr}$ concentration after nitro-perchloric acid digestion (Vega and Poppi, 1997) using inductively coupled plasma optical emission spectroscopy. Fecal samples from the ruminal metabolism trial were analyzed for total $\mathrm{N}$ using a combustion assay (Leco FP2000 N Analyzer; Leco Instruments Inc., St. Joseph, MI). Urine samples from the rumen metabolism trial were analyzed for creatinine, allantoin, and uric acid using an HPLC instrument (Pimpa et al., 2001) and for $\mathrm{N}$ by the micro-Kjeldahl procedure (AOAC, 1990).

Forage intake was calculated according to the following equation: forage intake $(\mathrm{kg} / \mathrm{d})=[$ total fecal production $(\mathrm{kg} / \mathrm{d})$ - fecal output from concentrate $(\mathrm{kg} / \mathrm{d})] /$ forage indigestibility (\%). Total fecal production was calculated as follows: total fecal production $(\mathrm{g} / \mathrm{d})=$ amount of marker dosed daily $(\mathrm{g} / \mathrm{d}) /$ concentration of marker in feces (\%). Fecal output coming from the concentrate was calculated according to the following formula: fecal output from concentrate $(\mathrm{kg} / \mathrm{d})=$ concentrate intake $(\mathrm{kg} / \mathrm{d}) /$ concentrate indigestibility (\%).

Microbial synthesis was estimated for the ruminal metabolism trial according to the method of Chen and Gomes (1992) from daily excretion of purine derivatives (allantoin and uric acid). Nitrogen intake for the lactation trial was calculated from intakes of concentrate and forage DM and their respective $\mathrm{N}$ contents. Apparent ENU (assuming no retention or mobilization of body $\mathrm{N}$ ) was calculated for each cow in the lactation trial by dividing mean milk $\mathrm{N}$ output (milk $\mathrm{CP} / 6.38$ ) by total $\mathrm{N}$ intake. Urinary $\mathrm{N}$ excretion for the ruminal metabolism trial was calculated from total urine production times its $\mathrm{N}$ content.

Ruminal fluid samples were thawed at room temperature and centrifuged $\left(15,000 \times g, 4^{\circ} \mathrm{C}, 30 \mathrm{~min}\right)$, and the supernatant was analyzed for VFA by gas chromatography (Palmquist and Conrad, 1971) and for $\mathrm{NH}_{3} \mathrm{~N}$ by the phenol-hypochlorite procedure (Chaney and Marbach, 1962).

\section{Statistical Analysis}

Results were analyzed using the Mixed procedure of SAS (SAS Institute, 2003) as a randomized incom- 
plete block design for the lactation trial and as a Latin square design for the ruminal metabolism trial. The model used for milk yield, milk composition, and PUN from the lactation trial, which had repeated measures taken from the same animals, included treatment, block, time of sampling (the repeated measures being week for milk and month for PUN), and the treatment $x$ time interaction as sources of variation. The model used for DM, N intake, pasture intake, and efficiency of $\mathrm{N}$ utilization from the lactation trial included treatment and block as sources of variation. In both models, all variables were considered fixed, except block and its interactions, which were considered random. Linear and quadratic effects of treatments were also estimated and are discussed in the text when significant.

For the ruminal metabolism trial, the model used for PUN, N excretion, and microbial synthesis data included treatment, cow, and period as sources of variation. The model used for ruminal parameters $(\mathrm{pH}$ and concentrations of VFA and $\mathrm{NH}_{3} \mathrm{~N}$ ), which were collected at different times after feeding, included treatment, period, cow, hours postfeeding (i.e., repeated measures), and the treatment $\times$ hours postfeeding interaction as sources of variation. In both models, all variables were considered fixed except cow, which was considered random. Two contrasts were also tested, one comparing the control treatment $(8.7 \% \mathrm{CP})$ with the 2 treatments with SSBM (13.4 and 18.1\% CP), referred to herein as control versus SSBM, and another comparing both treatments with $13.4 \% \mathrm{CP}$, referred herein as urea versus SSBM.

The covariance structure used for each repeatedmeasures analysis in both trials was chosen based on the parameters Akaike information criterion, corrected Akaike information criterion, and Bayesian information criterion of SAS. Least squares means and SEM are reported for all data. Significance was declared at $P<$ 0.05 . In both trials, after statistical analysis, the results of all variables were evaluated for normality of residuals and homogeneity of variances to identify outliers. Data were considered outliers and excluded from the data set when a Student's residual higher than 3 or lower than -3 was detected.

\section{RESULTS AND DISCUSSION}

\section{Pasture Composition}

The pasture chemical composition is presented in Table 2. The forage contents of NDF and lignin were lower and the $\mathrm{CP}$ contents were higher than usually found in tropical grasses (Tedeschi et al., 2002; CQBAL, 2010) as a consequence of intensive grazing management, $\mathrm{N}$ fertilization, and the sampling method (i.e., the part of the plant that was sampled). When the grazing management is adjusted to use the pasture at its optimal point (meaning variable grazing intervals), compared with fixed intervals, which for tropical grasses are traditionally longer than the average of the variable ones, not only is the forage offered to the animal of good quality, but the sward structure (a larger proportion of leaves) also increases the grazing efficiency (Carnevalli et al., 2006). Two previous studies conducted in the same area as the present study found higher milk yields when cows were managed under height-based variables than when they were managed under fixed grazing intervals (Carareto, 2007; Voltolini et al., 2010).

A linear increase in $\mathrm{CP}$ content and a decrease in NDF content was reported by Johnson et al. (2001) as $\mathrm{N}$ fertilization increased from 0 to $157 \mathrm{~kg}$ of $\mathrm{N} / \mathrm{ha}$ per cutting for all 3 tropical grasses evaluated. In vitro OM digestibility was increased by $\mathrm{N}$ fertilization in 2 out of the 3 grasses evaluated, increasing $\mathrm{N}$ fertilization protein fraction A more than the other fractions (Johnson et al., 2001). On the other hand, the pasture content of NFC was low (Table 2), as is usually observed in tropical grasses, which may cause an imbalance between energy and protein availability in the rumen, emphasizing the importance of energy supplementation in tropical grazing systems.

Protein fractions were calculated according to the CNCPS model (Sniffen et al., 1992) to better characterize the composition of the pasture under intensive management. The CNCPS fractionates CP into 5 fractions based on the solubility of protein precipitant agents, buffers, and detergent solutions. Fraction A represents the soluble NPN, B1 is the soluble true protein, B2 represents protein with intermediate rates of degradation, $\mathrm{B} 3$ is the CP insoluble in neutral detergent solution but soluble in acid detergent solution, and $\mathrm{C}$ is the unavailable N. The pasture CP consisted of $21.3 \%$ fraction $\mathrm{A}$, $9.2 \%$ fraction $\mathrm{B} 1,35.9 \%$ fraction $\mathrm{B} 2,28.8 \%$ fraction B3, and $4.8 \%$ fraction $\mathrm{C}$, suggesting that almost $65 \%$ of the protein had a medium to low degradation rate.

More recent studies that have evaluated intensively managed tropical pastures have shown a $\mathrm{CP}$ content ranging from 14.7 to $20.7 \%$ of DM (Cabral et al., 2000; Carareto, 2007; Romero, 2008; Martinez, 2008; Voltolini et al., 2008), with high proportions of medium- to lowdegradability fractions $(\mathrm{B} 2+\mathrm{B} 3=65.8$ to $70.2 \% \mathrm{CP}$; Cabral et al., 2000; Romero, 2008) and low degradation rates of the B fraction (4.98 to $6.05 \% / \mathrm{h}$; Martinez, 2008; Romero, 2008).

\section{Lactation Trial}

Concentrate ingredients and chemical compositions are presented in Table 2. Although the observed CP 
Table 3. Effect of $\mathrm{CP}$ in the concentrate of grazing dairy cows on DMI, milk yield and composition, MUN, plasma urea $\mathrm{N}$ (PUN), and efficiency of $\mathrm{N}$ use (ENU) in the lactation trial ${ }^{1}$

\begin{tabular}{|c|c|c|c|c|}
\hline Item & $8.7 \% \mathrm{CP}$ & $13.4 \% \mathrm{CP}$ & $18.1 \% \mathrm{CP}$ & $P$-value \\
\hline Total DMI, kg/d & $22.8 \pm 1.2$ & $20.7 \pm 1.1$ & $22.5 \pm 1.2$ & 0.16 \\
\hline Pasture DMI, $\mathrm{kg} / \mathrm{d}$ & $16.7 \pm 1.2$ & $14.6 \pm 1.1$ & $16.3 \pm 1.2$ & 0.18 \\
\hline Adjusted pasture DMI, ${ }^{2} \mathrm{~kg} / \mathrm{d}$ & $13.2 \pm 1.0$ & $11.5 \pm 0.9$ & $12.9 \pm 1.0$ & 0.20 \\
\hline Milk, $\mathrm{kg} / \mathrm{d}$ & $19.6 \pm 1.2$ & $19.1 \pm 1.2$ & $18.9 \pm 1.2$ & 0.55 \\
\hline Fat, $\%$ & $3.53 \pm 0.10$ & $3.45 \pm 0.10$ & $3.46 \pm 0.10$ & 0.78 \\
\hline Fat yield, $\mathrm{g} / \mathrm{d}$ & $677 \pm 32$ & $654 \pm 32$ & $653 \pm 32$ & 0.21 \\
\hline Protein, ${ }^{3} \%$ & $3.25 \pm 0.08$ & $3.23 \pm 0.08$ & $3.35 \pm 0.08$ & 0.51 \\
\hline Protein yield, ${ }^{3} \mathrm{~g} / \mathrm{d}$ & $626 \pm 34$ & $616 \pm 34$ & $633 \pm 34$ & 0.71 \\
\hline $\mathrm{CN}, \%$ & $2.59 \pm 0.07$ & $2.59 \pm 0.07$ & $2.69 \pm 0.07$ & 0.59 \\
\hline $\mathrm{CN}, \mathrm{g} / \mathrm{d}$ & $505 \pm 27$ & $491 \pm 27$ & $504 \pm 27$ & 0.73 \\
\hline ENU, \% & $18.4 \pm 1.1^{\mathrm{a}}$ & $16.2 \pm 1.0^{\mathrm{b}}$ & $15.5 \pm 1.1^{\mathrm{b}}$ & 0.01 \\
\hline Adjusted ENU, ${ }^{4} \%$ & $22.3 \pm 1.3^{\mathrm{a}}$ & $19.2 \pm 1.2^{\mathrm{b}}$ & $18.2 \pm 1.3^{\mathrm{b}}$ & 0.004 \\
\hline MUN, mg/dL & $8.3 \pm 0.4^{\mathrm{c}}$ & $10.4 \pm 0.4^{\mathrm{b}}$ & $13.3 \pm 0.4^{\mathrm{a}}$ & $<0.001$ \\
\hline PUN, mg/dL & $14.8 \pm 0.5^{\mathrm{b}}$ & $15.8 \pm 0.6^{\mathrm{ab}}$ & $17.7 \pm 0.6^{\mathrm{a}}$ & 0.002 \\
\hline
\end{tabular}

${ }^{\mathrm{a}-\mathrm{c}}$ Means within a row with different superscripts differ $(P<0.05)$.

${ }^{1}$ Numbers are expressed as mean \pm SEM.

${ }^{2}$ Pasture DMI adjusted for $82.5 \%$ fecal recovery of $\mathrm{Cr}_{2} \mathrm{O}_{3}$.

${ }^{3}$ Crude protein content and yield.

${ }^{4}$ Efficiency of $\mathrm{N}$ utilization considering the adjusted pasture DMI.

contents were higher than formulated, the planned differences among concentrate mixes were maintained. The replacement of corn by SSBM to increase the CP content also decreased NFC. However, the ivDMd was similar among concentrates, suggesting that the SSBM had the same digestibility as the finely ground corn. This was probably due to the lower starch digestibility of the flint corn grown in Brazil in comparison with North American dent corn (Correa et al., 2002). Regardless, it is important to notice that even with similar ivDMd, SSBM is not a source of fermentable carbohydrate as is the corn; therefore, the control diet provided higher amounts of rapidly fermentable carbohydrate than the 2 SSBM concentrates because of the greater inclusion of corn.

Dry matter and pasture intake, milk yield and composition, ENU, MUN, and PUN are presented in Table 3. Increasing concentrate $\mathrm{CP}$ levels did not affect any productive traits. Pasture intake was not increased with higher $\mathrm{CP}$ levels in the supplement, suggesting that the $\mathrm{N}$ available in the control concentrate was not limiting bacterial growth and fiber degradation, which otherwise could have caused intake limitations because of ruminal fill. Previous studies with either temperate (Bargo et al., 2001; McCormick et al., 2001) or tropical grasses (Wales et al., 2000; Pereira et al., 2009) also reported no response in pasture intake when the $\mathrm{CP}$ content of the concentrate was increased.

As a percentage of $\mathrm{BW}$, pasture intake averaged $3.33 \%$ and was overestimated in relation to NRC (2001) predictions, based on the inputs of BW, milk production levels, and concentrate intake of cows from our study. This may be due to partial fecal recovery of $\mathrm{Cr}_{2} \mathrm{O}_{3}$
(Hattan and Owen, 1969). Holden et al. (1994), using $\mathrm{Cr}_{2} \mathrm{O}_{3}$ as a fecal marker, found that the DMI of grass silage and hay was $10 \%$ higher than the DMI measured directly. Because fecal recovery was not measured in the present study, a correction index of 0.825 was used based on grazing studies from the literature (Oliveira et al., 2007; Ribeiro Filho et al., 2008) to adjust forage intake, as shown in Table 3. Another possibility for the overestimation of pasture DMI is the underestimation of the internal marker (indigestible DM) concentration in the feces because of incomplete recovery. Absolute values of pasture intake are difficult to compare among the few available studies with tropical grasses because of the different techniques used (i.e., different fecal markers with or without fecal recovery correction, pasture mass differences between pre- and postgrazing). Even though the limitations of measuring pasture intake make the absolute values less reliable, the data are still valuable for comparing treatments within studies.

No interaction was observed between treatment and week for milk yield or milk solids content and yield, and between treatment and month for PUN; therefore, average values are reported. Neither milk yield nor milk fat, protein, and CN contents or yields were affected by treatments (Table 3), indicating that the protein content of the pasture plus the energy supplement were sufficient to meet the requirements of the cows. Similar results were observed previously in studies with temperate grasses (Bargo et al., 2001; McCormick et al., 2001) that contained between 18.4 and $26.8 \% \mathrm{CP}$, either with medium-producing cows $(20.5 \mathrm{~kg} / \mathrm{d}$; Bargo et al., 2001$)$ or high-producing cows $(39.0 \mathrm{~kg} / \mathrm{d}$; McCormick et al., 2001). Likewise, studies conducted with elephantgrass 
containing 12 (Voltolini et al., 2008) and $13.9 \% \mathrm{CP}$ (Pereira et al., 2009) reported no response when the $\mathrm{CP}$ content of the concentrate was increased from 17 to 21 and $25 \%$ of DM (Voltolini et al., 2008) or from 15.2 to 18.2 and $21.1 \%$ of DM (Pereira et al., 2009), with cows averaging 16 (Pereira et al., 2009) and 18.2 $\mathrm{kg}$ of milk/d (Voltolini et al., 2008). All those studies indicated that energy was limiting milk production in grazing dairy cows. However, all the concentrates fed in these trials, even with lower CP levels, still contained some protein source. Fontaneli (2005) supplemented only energy concentrate (finely ground corn plus mineral mix) in a study with intensively managed tropical grasses containing between 20.6 and $22.1 \% \mathrm{CP}$ and observed milk yields of 20.4 to $26.7 \mathrm{~kg} / \mathrm{d}$ when cows received 5.5 to $7.2 \mathrm{~kg} / \mathrm{d}$ of the concentrate, suggesting that even with higher milk production, energy is the most limiting factor in well-managed grazing systems.

Those results are in agreement with previous studies in which grazing cows were fed increased levels of CP in the concentrate (Wales et al., 2000; Bargo et al., 2001; Voltolini et al., 2008; Pereira et al., 2009). The lack of response in milk fat content and yield as the CP level in the concentrate increased is another result suggesting that $\mathrm{N}$ availability in the rumen for bacterial growth and fiber degradation was adequate in animals consuming the control concentrate. Milk protein content and yield, as well as CN content and yield, did not respond to increased CP levels in the concentrate, leading to the conclusion that the limiting dietary nutrient for milk protein synthesis was energy, rather than MP.

The ENU (milk N/N intake) was calculated for both adjusted (corrected for partial fecal recovery of the marker) and nonadjusted pasture intakes (Table 3) and was linearly $(P<0.05)$ increased by $\mathrm{CP}$ content in the concentrate, being significantly greater for animals consuming the control treatment $(8.7 \% \mathrm{CP})$ because $\mathrm{N}$ intake was lower and milk $\mathrm{N}$ secretion was the same for all treatments. The ENU values found in this study, even when the adjusted values for forage intake were used $(21.5,19.4$, and $18.6 \%$ for the 8.7, 13.4, and $18.1 \%$ CP treatments, respectively; Table 3), were considered low for diets with the levels of $\mathrm{CP}$ fed in this study. Huhtanen and Hristov (2009) found an average ENU of $27.7 \%$ in a meta-analysis of 998 diets from Northern European experiments, with cows averaging $25.4 \mathrm{~kg}$ of milk/d (4.28\% fat and $3.2 \%$ protein) and $17.9 \mathrm{~kg}$ of $\mathrm{DMI} / \mathrm{d}$ of a $16.5 \% \mathrm{CP}$ diet. Another reason for the reduced ENU in the present study in addition to lower milk production, which would decrease the efficiency of nutrient utilization, was the likely overestimated forage intake, even with the correction for partial fecal recovery of $\mathrm{Cr}_{2} \mathrm{O}_{3}$, in comparison with the NRC
(2001) predictions. If the forage intake predicted by NRC (2001) were used in the calculation, the ENU for the control treatment would be $25.6 \%$.

The only change observed in milk composition when SSBM was included in the concentrates was a linear increase $(P<0.01)$ in MUN as the concentrate CP level increased (Table 3). This is indicative of greater $\mathrm{N}$ excretion in the urine of the cows consuming the concentrates with protein ingredients because MUN values are highly correlated with $\mathrm{N}$ content in the urine (Broderick and Clayton, 1997). Milk urea N values have been used as a reference to monitor protein status of the diet, as well as its energy:protein ratio (Hof et al., 1997) and ENU (Jonker et al., 1998). The MUN value found in the control treatment $(8.7 \% \mathrm{CP})$ was comparable with the lower range reported as ideal in the literature, from 8.5 to $11.5 \mathrm{mg} / \mathrm{dL}$ (Kohn et al., 2002), showing that even at the least $\mathrm{N}$ concentration levels, the animals received sufficient $\mathrm{CP}$ from the forage plus concentrate. Treatments affected MUN differently throughout the trial (significant interaction for treatment $\times$ week; $P<0.001$ ). During wk 7 , the differences among treatments were smaller (although they numerically ranked the same way) and not statistically different, and during wk 8, only the treatment with $18.1 \%$ CP was significantly higher than the other 2 treatments. The variation in MUN is most likely related to variations in pasture composition, mainly the $\mathrm{CP}$ and protein fractions, because pasture accounts for the greater CP portion of the diet.

Plasma urea $\mathrm{N}$ increased linearly $(P<0.001)$ when SSBM was included in the concentrate, although a significant difference among treatments was observed only for the higher level of inclusion $(18 \% \mathrm{CP})$. This indicates larger amounts of unutilized $\mathrm{N}$ in the rumen and duodenum provided by the SSBM. Plasma urea N values followed the pattern of MUN data, which was expected because PUN is positively and significantly correlated with MUN (Broderick and Clayton, 1997). Although we do not have data on $\mathrm{N}$ excretion for this trial, we can speculate that it was increased with the inclusion of soybean meal in the concentrates because the milk $\mathrm{N}$ secretion was similar and no BW gain differences were observed among treatments $(18.2,16.0$, and $22.6 \mathrm{~kg}$ for the treatments with 8.7, 13.4, and $18.1 \%$ $\mathrm{CP}$, respectively; $P=0.71$ ).

The CP content of the diets for the 3 treatments was estimated based on the average pasture intake among all cows (with and without correction for partial fecal recovery of $\mathrm{Cr}_{2} \mathrm{O}_{3}$ ). Without the correction, average pasture DMI was $15.86 \mathrm{~kg} / \mathrm{d}$, resulting in a diet forage:concentrate ratio of $72: 28$, which would lead to diets with $15.7,17.0$, and $18.3 \% \mathrm{CP}$ for treatments 
8.7, 13.4, and $18.1 \% \mathrm{CP}$, respectively. When pasture DMI was corrected for partial fecal recovery of $\mathrm{Cr}_{2} \mathrm{O}_{3}$ $(12.56 \mathrm{~kg}$ of $\mathrm{DM} / \mathrm{d})$, the diet forage:concentrate ratio became $67: 33$, leading to $15.3,16.8$, and $18.4 \% \mathrm{CP}$ for the 3 treatments, respectively. Because no response of DMI and milk yield and composition was observed with protein supplementation (concentrates with 13.4 and $18.1 \% \mathrm{CP}$ ), we concluded that the dietary CP content that met the requirements of midlactation grazing cows producing approximately $20 \mathrm{~kg} / \mathrm{d}$ and that provided the greatest ENU was between 15.3 and $15.7 \%$ when they were consuming on average $6.1 \mathrm{~kg}$ of finely ground flint corn.

According to NRC (2001), using the inputs provided by our study, the CP content of the diet necessary to support $20 \mathrm{~kg}$ of milk/d would be $14.5 \%$. Similarly, Wales et al. (2000) and Pereira et al. (2009) found 13.7 and $14.7 \%$ were the optimal dietary CP contents for cows producing 21 and $16 \mathrm{~kg} / \mathrm{d}$, respectively. All those values are lower than that reported by Olmos Colmenero and Broderick (2006) of $16.5 \%$ as the optimal CP content for cows producing 35 to $40 \mathrm{~kg} / \mathrm{d}$ and are much lower than the optimal dietary CP contents reported by NRC (2001), of 23\%, and by Ipharraguerre and Clark (2005), of $22.8 \%$. However, those trials used higherproducing cows than in the present experiment, which have higher nutritional requirements.

It is important to notice that the control treatment also provided the highest supply of fermentable carbohydrate, which allowed for a better balance between protein and energy in the rumen and led to higher ENU. Hence, because grazing management techniques improve the nutritive value of tropical grasses, mainly the $\mathrm{CP}$ content, it is necessary to use the concentrate to balance the diet, adjusting for adequate amounts and sources of carbohydrates, aiming to improve the efficiency of utilization of both protein and carbohydrates in the rumen. The present study did not aim to determine an adequate carbohydrate amount or fermentability, but rather to evaluate the response to protein supplementation that, as a consequence, altered the diet NFC content. However, the lack of response might open a new research approach, namely, looking at different sources of carbohydrate to supplement lactating cows grazing intensively managed tropical grasses.

Another approach that could potentially lead to a different response is the supplementation with a highquality undegradable protein source. However, no support is available in the literature for supplementing cows producing approximately $20 \mathrm{~kg}$ of milk/d or less with high-quality undegradable protein sources (Delgado and Randel, 1989; Kellaway and Porta, 1993; Santos et al., 1998; NRC, 2001).

\section{Rumen Metabolism Trial}

Ruminal pH, ruminal concentrations of VFA and $\mathrm{NH}_{3} \mathrm{~N}$, microbial synthesis, and PUN are presented in Table 4 . The interaction between time after feeding and treatment was not significant $(P>0.05)$ for any ruminal characteristic; therefore, average values are reported. Ruminal $\mathrm{pH}$ of the 4 treatments remained above 6.4 at all sampling times, showing that the amount of fermentable carbohydrates through the concentrates did not impair the ruminal environment or ruminal function. Ruminal $\mathrm{NH}_{3} \mathrm{~N}$ concentration was greater for treatments with $\mathrm{N}$ supplements (SSBM and urea) than for the $8.7 \% \mathrm{CP}$ concentrate diet. This result was expected because both $\mathrm{N}$ ingredients used are high in RDP content (100\% of CP for urea and $65 \%$ of CP for soybean meal; NRC, 2001). Energy supplementation for cows grazing pastures with a high CP content allows for better energy-protein synchrony in the rumen, improving the utilization of $\mathrm{N}$ to synthesize microbial protein and, as a result, decreasing $\mathrm{NH}_{3} \mathrm{~N}$ concentration in the ruminal fluid (Poppi and McLennan, 1995; Kolver et al., 1998). The ruminal $\mathrm{NH}_{3} \mathrm{~N}$ concentration of $9.41 \mathrm{mg} / \mathrm{dL}$ in the $8.7 \% \mathrm{CP}$ concentrate treatment was greater than $5 \mathrm{mg} / \mathrm{dL}$, the value recommended by Satter and Slyter (1974) as optimal for microbial synthesis. On the other hand, Soder and Gregorini (2010) worked with continuous culture fermenters, evaluating 4 levels of $\mathrm{CP}$ in the concentrate of a 40:60 concentrate:forage ratio diet, and found a reduction in microbial synthesis when the ruminal $\mathrm{NH}_{3}$ concentration was greater than $19 \mathrm{mg} /$ dL. Kertz (2010), in a recent review of feeding urea to dairy cattle, suggested that the optimal ruminal $\mathrm{NH}_{3} \mathrm{~N}$ concentration to maximize DM digestion increased as the fermentability of the feed increased. Regardless of the theoretical optimal level, in the present study, the higher levels of $\mathrm{NH}_{3} \mathrm{~N}$ concentration in the treatments with protein ingredients were not accompanied by increases in microbial synthesis (see Discussion section below). High $\mathrm{NH}_{3} \mathrm{~N}$ concentrations reflect an excess of $\mathrm{N}$ not used for microbial synthesis that needs to be excreted in an energy-required process. Therefore, part of the energy that could be used for milk production needs to be redirected to urea synthesis and excretion, reducing milk yield efficiency (Russell et al., 1983; Kolver et al., 1998).

Ruminal concentrations of acetate, propionate, and butyrate were not affected by treatments (Table 4), which suggests no difference in feed digestion with $\mathrm{N}$ supplementation for those cows. These data agree with those of Jones-Endsley et al. (1997) and Bargo et al. (2001), who reported similar proportions of individual VFA in grazing dairy cows supplemented with concentrates of different CP levels. Branched-chain VFA 
Table 4. Effect of dietary $\mathrm{N}$ content and source on ruminal metabolites, microbial synthesis, and plasma urea $\mathrm{N}$ (PUN) in the ruminal metabolism trial

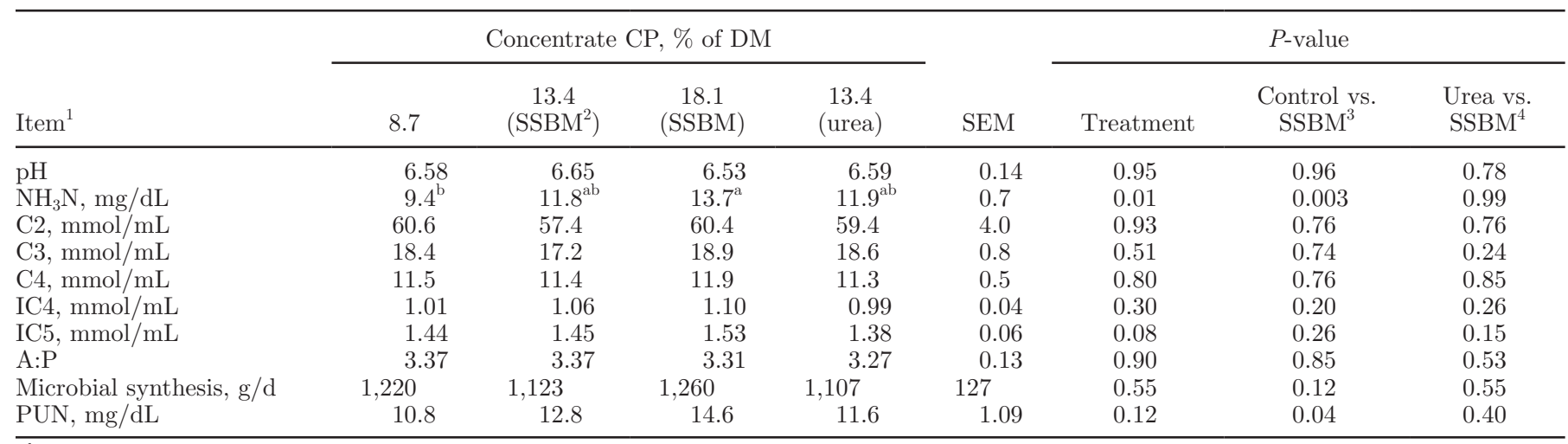

$\overline{\mathrm{a}, \mathrm{b}}$ Means within a row with different superscripts differ $(P<0.05)$.

${ }^{1} \mathrm{C} 2$ = acetate; $\mathrm{C} 3$ = propionate; $\mathrm{C} 4=$ butyrate; IC4 = isobutyrate; IC5 = isovalerate; $\mathrm{A}: \mathrm{P}$ = acetate:propionate ratio.

${ }^{2} \mathrm{SSBM}=$ solvent-extracted soybean meal.

${ }^{3}$ Contrast between the control diet $(8.7 \% \mathrm{CP})$ and the average of the 2 diets with SSBM $(13.4$ and $18.1 \% \mathrm{CP})$.

${ }^{4}$ Contrast between the 2 diets with $13.4 \%$ CP, with SSBM or urea.

(isobutyrate and isovalerate) are formed from valine and leucine degradation, respectively, and in the present study, the concentration of isovalerate was numerically higher in the $18.1 \% \mathrm{CP}$ and smaller in the $13.4 \%$ $\mathrm{CP}$ with urea treatments $(P=0.076)$, agreeing with the greater availability of AA for degradation in the concentrate with SSBM.

Nitrogen supplementation in the concentrate did not increase microbial synthesis (Table 4), corroborating the results presented thus far showing that protein was not the limiting nutrient for either bacteria growth or milk and protein yield. Therefore, the inclusion of $\mathrm{N}$ sources in the diet led to an excess of $\mathrm{N}$ in the rumen, reflected by a higher concentration of $\mathrm{NH}_{3} \mathrm{~N}$ (Table 4), which is absorbed by the ruminal epithelium into the bloodstream. This explains the high positive correlation between ruminal $\mathrm{NH}_{3}$ and $\mathrm{PUN}$ values (Huhtanen and Hristov, 2009). In the present study, BUN was not significantly different between treatments (Table 4); however, the $8.7 \% \mathrm{CP}$ concentrate led to lower PUN than the 2 SSBM concentrates (contrast: control vs. SSBM; $P=0.045)$.

Fecal $\mathrm{N}$ concentration was not affect by treatments (Table 5). Fecal $\mathrm{N}$ excretion is usually altered little by dietary CP content, which has been confirmed in several studies (Peyraud and Astigarraga, 1998; Castillo et al., 2001; Mulligan et al., 2004; Marini and Van Amburgh, 2005; Zanton and Heinrichs, 2008). Urine, on the other hand, is the major route for $\mathrm{N}$ excretion, so urinary $\mathrm{N}$ output is very likely to increase in response to increased $\mathrm{N}$ intake (Mulligan et al., 2004). This has an important environmental impact, given that much of the urinary $\mathrm{N}$ can be volatilized as $\mathrm{NH}_{3}$ and has a greater capacity for soil penetration (Pakrou and Dillon, 1995) in relation to fecal N (Lockyer and Whitehead, 1990), leading to air and water contamination. In the present study, both urinary $\mathrm{N}$ content $(\%)$ and excretion $(\mathrm{g} / \mathrm{d})$ were numerically lower for the control treatment $(P=0.084$ and $P=0.067$, respectively; Table 5) and significantly lower compared with the 2 treatments with SSBM

Table 5. Effect of dietary $\mathrm{N}$ content and source on $\mathrm{N}$ excretion in the ruminal metabolism trial

\begin{tabular}{|c|c|c|c|c|c|c|c|c|}
\hline \multirow[b]{2}{*}{ Item } & \multicolumn{4}{|c|}{ Concentrate CP, \% of DM } & \multirow[b]{2}{*}{ SEM } & \multicolumn{3}{|c|}{$P$-value } \\
\hline & 8.7 & $\begin{array}{c}13.4 \\
\left(\mathrm{SSBM}^{1}\right)\end{array}$ & $\begin{array}{c}18.1 \\
(\mathrm{SSBM})\end{array}$ & $\begin{array}{c}13.4 \\
\text { (urea) }\end{array}$ & & Treatment & $\begin{array}{l}\text { Control vs. } \\
\mathrm{SSBM}^{2}\end{array}$ & $\begin{array}{l}\text { Urea vs. } \\
\text { SSBM }^{3}\end{array}$ \\
\hline Fecal N, \% & 2.62 & 2.67 & 2.62 & 2.55 & 0.06 & 0.49 & 0.72 & 0.14 \\
\hline Urine N, \% & 5.08 & 6.15 & 7.31 & 6.55 & 0.89 & 0.08 & 0.03 & 0.58 \\
\hline Urine $\mathrm{N}, \mathrm{g} / \mathrm{d}$ & 89 & 126 & 135 & 132 & 13.06 & 0.07 & 0.02 & 0.70 \\
\hline
\end{tabular}

${ }^{1} \mathrm{SSBM}=$ solvent-extracted soybean meal.

${ }^{2}$ Contrast between the control diet $(8.7 \% \mathrm{CP})$ and the average of the 2 diets with SSBM (13.4 and $\left.18.1 \% \mathrm{CP}\right)$.

${ }^{3}$ Contrast between the 2 diets with $13.4 \% \mathrm{CP}$, with SSBM or urea. 
(contrast: control vs. SSBM; $P=0.033$ and $P=0.018$, respectively; Table 5), as expected.

\section{CONCLUSIONS}

Midlactation dairy cows producing approximately 20 $\mathrm{L} / \mathrm{d}$, grazing intensively managed tropical grasses with high levels of $\mathrm{CP}$, did not respond to protein supplementation through the inclusion of SSBM in the concentrate. Therefore, the supplementation of an $8.7 \% \mathrm{CP}$ concentrate, resulting in a diet with $\mathrm{CP}$ levels between 15.3 and $15.7 \%$ of DM and more fermentable carbohydrate, was sufficient to meet the protein requirements of such milk production with the highest ENU.

The inclusion of protein ingredients in the concentrate did not improve any variable that could lead to better production, such as nutrient digestion or microbial synthesis, but only to increased concentrations of PUN, MUN, and ruminal $\mathrm{NH}_{3}$, indicating a smaller ENU and greater $\mathrm{N}$ excretion. Nitrogen wastage is problematic not only from an environmental standpoint, such as water and air contamination, but also from an economic point of view because $\mathrm{N}$ is the nutrient that most influences the cost of the diet.

\section{ACKNOWLEDGMENTS}

This study was partially funded by The State of São Paulo Research Foundation (FAPESP, São Paulo, Brazil). The authors thank the staff from the Department of Animal Science of the University of Sao Paulo (Piracicaba, Brazil), especially Carlos Cesar Alves and Carla Maris Bittar for their help in the laboratory analysis, and Marco Antonio Penati, Laureano Alves da Silva, Joaquim de Oliveira, Primo José Gerage, and Francisco "Neco" Andrade for their help with the field work.

\section{REFERENCES}

AOAC. 1990. Official Methods of Analysis. 12nd ed. Assoc. Off. Anal. Chem., Gaithersburg, MD.

Bargo, F., D. H. Rearte, F. J. Santini, and L. D. Muller. 2001. Ruminal digestion by dairy cows grazing winter oats pasture supplemented with different levels and sources of protein. J. Dairy Sci. 84:2260-2272.

Broderick, G. A., and M. K. Clayton. 1997. A statistical evaluation of animal and nutritional factors influencing concentrations of milk urea nitrogen. J. Dairy Sci. 80:2964-2971.

Cabral, L. S., S. C. Valadares Filho, P. A. M. Malafaia, R. P. De Lana, J. F. Coelho Da Silva, R. A. M. Vieira, and E. S. Pereira. 2000. Forage carbohydrate fractions and its degradation rates estimated by gas production techniques. Braz. J. Anim. Sci. 29:2087-2098.

Carareto, R. 2007. The use of a slow release urea for cows fed corn silage or elephant-grass pastures managed with fixed or variable grazing intervals. Master's Thesis. University of São Paulo, Piracicaba, Brazil.
Carnevalli, R. A., S. C. Da Silva, A. A. O. Bueno, M. C. Uebele, F. O. Bueno, G. N. Silva, and J. P. Moraes. 2006. Herbage production and grazing losses in Panicum maximum cv. Mombaça under four grazing managements. Trop. Grassl. 40:165-176.

Casali, A. O., E. Detmann, S. C. Valadares Filho, J. C. Pereira, L. T. Henriques, S. G. Freitas, and M. F. Paulino. 2008. Influence of incubation time and particles size on indigestible compounds contents in cattle feeds and feces obtained by in situ procedures. Braz. J. Anim. Sci. 37:335-342.

Castillo, A. R., E. Kebreab, D. E. Beever, J. H. Barbi, J. D. Sutton, H. C. Kirby, and J. France. 2001. The effect of protein supplementation on nitrogen utilization in lactating dairy cows fed grass silage based diets. J. Anim. Sci. 79:247-253.

Chaney, A. L., and E. P. Marbach. 1962. Modified reagents for determination of urea and ammonia. Clin. Chem. 8:130-132.

Chen, X. B., and M. J. Gomes. 1992. Estimation of microbial protein supply to sheep and cattle based on urinary excretion of purine derivatives - An overview of the technical details. International Feed Resources Unit, Rowett Research Institute, Aberdeen, UK.

Chizzotti, M. L., S. C. Valadares Filho, R. F. D. Valadares, F. H. M. Chizzotti, and L. O. Tedeschi. 2008. Determination of creatinine excretion and evaluation of spot urine sampling in Holstein cattle. Livest. Sci. 113:218-225.

Correa, C. E. S., R. D. Shaver, M. N. Pereira, J. G. Lauer, and K. Kohn. 2002. Relationship between corn vitreous and ruminal in situ starch degradability. J. Dairy Sci. 85:3008-3012.

CQBAL. 2010. Chemical and bromatologic composition of Brazilian feeds [software]. Accessed Jul. 23, 2010. http://www.ufv.br/cqbal.

Da Silva, S. C., and D. Nascimento Junior. 2007. Research advances on tropical pasture: Morphophysiological characteristics and grazing management. Braz. J. Anim. Sci. 36:121-138.

De Vries, M. F. W. 1995. Estimating forage intake and quality in grazing cattle: A reconsideration of the hand-plucking method. J. Range Manage. 48:370-375.

Delgado, I., and P. F. Randel. 1989. Supplementation of cows grazing tropical grass swards with concentrates varying in protein level and degradability. J. Dairy Sci. 72:995-1001.

Fonseca, L., J. C. Mezzalira, C. Bremm, R. S. A. Filho, H. L. Gonda, and P. C. F. Carvalho. 2012. Management targets for maximising the short-term herbage intake rate of cattle grazing in sorghum bicolor. Livest. Sci. 145:205-211.

Fontaneli, R. S. 2005. Milk production of Holstein cows under tropical perennial grass pasture in Planalto Medio of Rio Grande do Sul. PhD Diss. Agronomy College, Federal University of Rio Grande do Sul, Porto Alegre, Brazil.

Giacomini, A. A., S. C. Da Silva, D. O. L. Sarmento, C. V. Zeferino, S. J. Souza Jr., J. K. Trindade, V. D. Guarda, and D. Nascimento Jr. 2009. Growth of marandu palisadegrass subjected to strategies of intermittent stocking. Sci. Agric. 66:733-741.

Goering, H. K., and P. J. Van Soest. 1970. Forage Fiber Analysis. Handb. No. 379. Agric. Res. Serv., US Dept. of Agric., Washington, DC.

Hattan, G. L., and F. G. Owen. 1969. Efficiency of total collection and chromic oxide techniques in short-term digestion trials. J. Dairy Sci. 53:325-329.

Hof, G., M. D. Vervoorn, P. L. Lenaers, and S. Tamminga. 1997. Milk urea nitrogen as a tool to monitor the protein nutrition of dairy cows. J. Dairy Sci. 80:3333-3340.

Holden, L. A., L. D. Muller, G. A. Varga, and P. J. Hillard. 1994. Ruminal digestion and duodenal nutrient flows in dairy cows consuming grass as pasture, hay, or silage. J. Dairy Sci. 77:3034-3042.

Huhtanen, P., and A. N. Hristov. 2009. A meta-analysis of the effects of dietary protein concentration and degradability on milk protein yield and milk $\mathrm{N}$ efficiency in dairy cows. J. Dairy Sci. 92:3222-3232.

Ipharraguerre, I. R., and J. H. Clark. 2005. Impacts of the source and amount of crude protein on the intestinal supply of nitrogen fractions and performance of dairy cows. J. Dairy Sci. 88(Suppl. 1):E22-E37.

Johnson, C. R., B. A. Reiling, P. Mislevy, and M. B. Hall. 2001. Effects of nitrogen fertilization and harvest date on yield, digest- 
ibility, fiber, and protein fractions of tropical grasses. J. Anim. Sci. $79: 2439-2448$.

Jones-Endsley, J. M., M. J. Cecava, and T. R. Johnson. 1997. Effects of dietary supplementation on nutrient digestion and the milk yield of intensively grazed lactating dairy cows. J. Dairy Sci. 80:3283-3292.

Jonker, J. S., R. A. Kohn, and R. A. Erdman. 1998. Using milk urea nitrogen to predict nitrogen excretion and utilization efficiency in lactating dairy cows. J. Dairy Sci. 81:2681-2692.

Kellaway, R., and S. Porta. 1993. Feeding Concentrates: Supplements for Dairy Cows. Dairy Res. Dev. Corp., Glen Iris, Victoria, Australia.

Kertz, A. F. 2010. Urea feeding to dairy cattle: A historical perspective and review. Prof. Anim. Sci. 26:257-272.

Kohn, R. A., K. F. Kalscheur, and E. Russek-Cohen. 2002. Evaluation of models to estimate urinary nitrogen and expected milk urea nitrogen. J. Dairy Sci. 85:227-233.

Kolver, E., L. D. Muller, G. A. Varga, and T. J. Cassidy. 1998. Synchronization of ruminal degradation of supplemental carbohydrate with pasture nitrogen in lactating dairy cows. J. Dairy Sci. 81:2017-2028

Krishnamoorthy, U. C., T. V. Muscato, C. J. Sniffen, and P. J. Van Soest. 1982. Nitrogen fractions in selected feedstuffs. J. Dairy Sci. 65:217-225.

Licitra, G., T. M. Hernandez, and P. J. Van Soest. 1996. Standardization of procedures for nitrogen fractionation of ruminant feeds. Anim. Feed Sci. Technol. 57:347-358.

Lockyer, D. R., and D. C. Whitehead. 1990. Volatilization of ammonia from cattle urine applied to grassland. Soil Biol. Biochem. $22: 1137-1142$.

Lopes, J. C. 2011. Nutrient composition and fiber digestibility measurements of tropical forages collected from intensively managed rotational grazing systems. Master's Thesis. University of Wisconsin-Madison.

Marini, J. C., and M. E. Van Amburgh. 2005. Partition of nitrogen excretion in urine and the feces of holstein replacement heifers. J. Dairy Sci. 88:1778-1784.

Martinez, J. C. 2008. Evaluation of by-products to feed dairy cows grazing tropical grasses during the rainy season and fed in the confinement during the dry season. PhD Diss. University of São Paulo, Piracicaba, Brazil.

McCormick, M. E., J. D. Ward, D. D. Redfearn, D. D. French, D. C. Blouin, V. Chapa, and J. M. Fernandez. 2001. Supplemental dietary protein for grazing dairy cows: Effect on pasture intake and lactation performance. J. Dairy Sci. 84:896-907.

Mulligan, F. J., P. Dillon, J. J. Callan, M. Rath, and F. P. O'mara. 2004. Supplementary concentrates type affects nitrogen excretion of grazing dairy cows. J. Dairy Sci. 87:3451-3460.

NRC. 1989. Nutrient Requirements of Dairy Cattle. 6th rev. ed. Natl. Acad. Sci., Washington, DC.

NRC. 2001. Nutrient Requirements of Dairy Cattle. 7th rev. ed. Natl. Acad. Sci., Washington, DC.

Oliveira, D. E., S. R. Medeiros, L. O. Tedeschi, L. J. M. Aroeira, and S. C. Silva. 2007. Estimating forage intake of lactating dual-purpose cows using chromium oxide and $n$-alkanes as external markers. Sci. Agric. 64:103-110.

Olmos Colmenero, J. J., and G. A. Broderick. 2006. Effect of dietary crude protein concentration on milk production and nitrogen utilization in lactating dairy cows. J. Dairy Sci. 89:1704-1712.

Pakrou, N., and P. Dillon. 1995. Preferential flow, nitrogen transformations and ${ }^{15} \mathrm{~N}$ balance under urine affected areas of irrigated and non-irrigated clover based pastures. J. Contam. Hydrol. 20:329347.

Palhano, A. L., P. C. F. Carvalho, J. R. Dittrich, A. Moraes, S. C. Da Silva, and A. L. G. Monteiro. 2007. Forage intake characteristics on mombaçagrass pastures grazed by Holstein heifers. Braz. J. Anim. Sci. 34:1860-1870.

Palmquist, D. L., and H. R. Conrad. 1971. Origin of plasma fatty acid in lactating dairy cows fed high fat diets. J. Dairy Sci. 54:10251033.
Parsons, A. J., I. R. Johsnson, and A. Harvey. 1988. Use of a model to optimize the interaction between frequency and severity of intermittent defoliation to provide a fundamental comparison of the continuous and intermittent defoliation of grass. Grass Forage Sci. 43:49-59.

Pedreira, C. G. S., F. A. A. Rosseto, S. C. Da Silva, L. G. Nussio, L. S B. Moreno, M. L. P. Lima, and P. R. Leme. 2005. Forage yield and grazing efficiency on rotationally stocked pastures of 'Tanzania-1' guineagrass and 'Guaçu' elephantgrass. Sci. Agric. 62:433-439.

Pereira, F. R., H. M. Saturnino, E. O. S. Saliba, L. C. Gonçalves, R. B. Reis, P. A. B. Miranda, R. C. Mourão, D. T. Silvetre, and P. N. S. Caldeira. 2009. Protein contents for lactating dairy cows grazing elephant grass. Braz. J. Vet. Anim. Sci. 61:1139-1147.

Peyraud, J. L., and L. Astigarraga. 1998. Review of the effect of nitrogen fertilization on the chemical composition, intake, digestion and nutritive value of fresh herbage: Consequences on animal nutrition and N balance. Anim. Feed Sci. Technol. 72:235-259.

Pimpa, O., J. B. Liang, Z. A. Jelan, and N. Abdullah. 2001. Urinary excretion of duodenal purine derivatives in Kedah-kelantan cattle. Anim. Feed Sci. Technol. 92:203-214.

Poppi, D. P., and S. R. McLennan. 1995. Protein and energy utilization by ruminants at pasture. J. Anim. Sci. 73:278-290.

Ribeiro Filho, H. M. N., F. C. Zimermann, and G. V. Kozloski. 2008. Use of low dose of chromium oxide to estimate fecal production of bovines. Cienc. Rural 38:2567-2573.

Romero, J. V. 2008. Carbohydrates and nitrogen compounds of Elephant grass (Pennisetum purpureum) cv. Cameron managed with fixed or variable interval of defoliation. Master's Thesis. University of São Paulo, Piracicaba, Brazil.

Russell, J. B., C. J. Sniffen, and P. J. Van Soest. 1983. Effect of carbohydrate limitation on degradation and utilization of casein by mixed rumen bacteria. J. Dairy Sci. 66:763-775.

Santos, F. A. P., A. M. Pedroso, J. C. Martinez, and M. A. Penatti. 2005. Use of concentrate supplementation for dairy cows grazing tropical grasses. Pages 289-346 in Proc. 5th Symp. Dairy Prod. Fundação de Estudos Agrários "Luiz de Queiroz" (FEALQ), Piracicaba, Brazil.

Santos, F. A. P., J. E. P. Santos, C. B. Theurer, and J. T. Huber 1998. Effects of rumen undegradable protein on dairy cow's performance: A 12-year literature review. J. Dairy Sci. 81:3182-3213.

SAS Institute. 2003. SAS/STAT. Release 9.1. SAS Institute Inc., Cary, NC.

Satter, L. D., and L. L. Slyter. 1974. Effect of ammonia concentration on rumen microbial protein production in vitro. Br. J. Nutr. 32:199-208.

Sniffen, C. J., J. D. O'Connor, P. J. Van Soest, D. G. Fox, and J. B. Russell. 1992. A net carbohydrate and protein system for evaluating cattle diets: II. Carbohydrate and protein availability. J. Anim. Sci. 70:3562-3577.

Soder, K. J., and P. Gregorini. 2010. Relationship between supplemental protein and ruminal fermentation of an herbage diet. Prof. Anim. Sci. 26:290-297.

Stangassinger, M., X. B. Chen, J. E. Lindberg, and D. Giesecke. 1995. Metabolism of purines in relation to microbial production. Pages 387-406 in Ruminant Physiology: Digestion, Metabolism, Growth and Reproduction. W. V. Engelhardt, S. Leonhardmarek, G. Breves, and D. Giesecke, ed. Enke-Verlag, Stuttgart, Germany.

Stobbs, T. H. 1973. The effect of plant structure on the intake of tropical pastures. II. Differences in sward structure, nutritive value, and bite size of animals grazing Setaria anceps and Chloris gayana at various stages of growth. Aust. J. Agric. Res. 24:821-829.

Tamminga, S. 1992. Nutrition management of dairy cows as a contribution of pollution control. J. Dairy Sci. 75:345-357.

Tedeschi, L. O., D. G. Fox, J. B. Russell, A. N. Pell, D. P. D. Lanna, and C. Boin. 2002. Development and evaluation of a tropical feed library for the Cornell Net Carbohydrate and Protein System model. Sci. Agric. 59:1-18.

Tilley, J. M. A., and R. A. Terry. 1963. A two stages technique for the "in vitro" digestion of forage crops. J. Br. Grassl. Soc. 18:104-111. 
Valadares, R. F. D., G. A. Broderick, S. C. Valadares Filho, and M. K. Clayton. 1999. Effect of replacing alfalfa silage with high moisture corn on ruminal protein synthesis estimated from excretion of total purine derivatives. J. Dairy Sci. 82:2686-2696.

Van Soest, P. J., J. B. Robertson, and B. A. Lewis. 1991. Methods for dietary fiber, neutral detergent fiber and nonstarch polysaccharides in relation to animal nutrition. J. Dairy Sci. 74:3583-3597.

Vega, A., and D. P. Poppi. 1997. Extent of digestion and rumen condition as factors affecting passage of liquid and digesta particles in sheep. J. Agric. Sci. 128:207-215.

Voltolini, T. V., F. A. P. Santos, J. C. Martinez, H. Imaizumi, R. L. Clarindo, and M. A. Penati. 2010. Milk production and composition of dairy cows grazing elephant grass under two grazing intervals. Braz. J. Anim. Sci. 39:121-127.
Voltolini, T. V., F. A. P. Santos, J. C. Martinez, H. Imaizumi, A. V. Pires, and M. A. Penati. 2008. Metabolizable protein supply according to the NRC (2001) for dairy cows grazing elephant grass. Sci. Agric. 65:130-138.

Wales, W. J., D. W. Dellow, and P. T. Doyle. 2000. Protein supplementation of cows grazing limited amounts of paspalum (Paspalum dilatatum Poir.)-dominant irrigated pasture in mid-lactation. Aust. J. Exp. Agric. 40:923-929.

Weiss, W. P., H. R. Conrad, and R. S. Pierre. 1992. A theoreticallybase model for predicting total digestible nutrient values of a forages and concentrates. Anim. Feed Sci. Technol. 39:95-119.

Zanton, G. I., and A. J. Heinrichs. 2008. Analysis of nitrogen utilization and excretion in growing dairy cattle. J. Dairy Sci. 91:15191533. 